\title{
UPAYA MENINGKATKAN AKTIVITAS DAN HASIL BELAJAR ALAT UKUR DENGAN MENGGUNAKAN MULTIMEDIA INTERAKTIF PADA SISWA KELAS $X$ DI SMK AL-WASHLIYAH 4 MEDAN
}

\author{
Marisa Wati Siregar ${ }^{1}$, Julaga Situmorang ${ }^{2}$ \\ Teknologi Pendidikan Pascasarjana Universitas Negeri Medan \\ Marisa_watisiregar@yahoo.com ${ }^{1}$
}

\begin{abstract}
Abstrak: Penelitian ini bertujuan untuk: (1) Mengetahui peningkatan aktivitas belajar siswa pada pelajaran Alat Ukur dengan penggunaan Multimedia Interaktif.(2) Mengetahui peningkatan hasil belajar siswa pada pelajaran Alat Ukur dengan penggunaan multimedia interaktif. Penelitian ini merupakan penelitian tindakan kelas. Subjek penelitian adalah seluruh siswa kelas X SMK AlWashliyah 4 terdiri dari satu kelas dengan jumlah sampel 32 orang. Objek pada penelitian ini adalah penguatan struktur kognitif yang diukur melalui hasil belajar dan aktifitas belajar siswa dalam pembelajaran. Penelitian ini terdiri dari 2 siklus, siklus pertama terdiri dari 2 pertemuan dan siklus kedua terdiri dari 2 pertemuan. Tes hasil belajar dilakukan di akhir setiap siklus. Tes hasil belajar terdiri dari 20 soal. Hasil penelitian yaitu : (1) Terdapat peningkatan hasil belajar siswa yang ditunjukkan dari peningkatan rata-rata skor tes hasil belajar sebesar 3,78 poin, persentase ketuntasan sebesar $61,50 \%$ dan peningkatan nilai tes hasil belajar dengan nilai Gain ternormalisasi sebesar 0,31 berkategori sedang. (2) Penggunaan multimedia interaktif macromedia flash dapat meningkatkan aktivitas dengan hasil observasi terhadap aktivitas pembelajaran guru di kelas, aktifitas belajar siswa meningkat sebesar $32.81 \%$, yaitu dari $46,14 \%$ pada siklus pertama menjadi $78,96 \%$ pada siklus kedua. Hal ini menunjukan aktifitas belajar tergolong pada kategori aktif.
\end{abstract}

Kata Kunci: aktivitas dan hasil belajar alat ukur, menggunakan multimedia interaktif

\begin{abstract}
This study aimed to: (1) Determine the increased activity of students in a lesson Measurement with the use of Interactive Multimedia. (2) Determine improving student learning outcomes in the subject Measuring the use of interactive multimedia. This research is a class act. The subjects were all students of class X SMK Al-Washliyah 4 consist of one class with a sample size of 32 people. The object of this research is to strengthen the cognitive structure as measured through learning outcomes and learning activities of students in learning. This study consisted of two cycles, the first cycle consists of two meetings and the second cycle consists of two meetings. Achievement test conducted at the end of each cycle. Achievement test consisting of 20 questions. Results of the study are: (1) There is an increased student learning outcomes as indicated by the increase in the average achievement test score of 3.78 points, the percentage of completeness of $61.50 \%$ and an increase in test scores of learning outcomes with Gain normalized value of 0.31 moderate category. (2) Use of Macromedia Flash interactive multimedia can enhance the activity with the result of observation of teachers in the classroom learning activities, and learning activities of students increased by $32.81 \%$, from $46.14 \%$ in the first cycle into $78.96 \%$ in the second cycle. This shows the learning activities belonging to the active category.
\end{abstract}

Keywords: activity and learning outcomes measurement tool, using interactive multimedia

\section{PENDAHULUAN}

Tujuan pembelajaran dapat tercapai apabila pembelajaran direncanakan dengan baik dan matang. Dalam hal ini guru harus dapat memilih kegiatan pembelajaran yang efektif dan efesien untuk menciptakan pengalaman belajar yang baik dan dapat menyediakan fasilitas belajar kepada peserta didik.
Berdasarkan observasi yang penulis lakukan pada siswa kelas X SMK Al-Washliyah 4 Medan diperoleh keterangan bahwa hasil belajar Alat Ukur siswa tersebut masih tergolong rendah. Hal ini dapat dilihat dari hasil nilai Ujian Akhir semester kelas X SMK Al-Washliyah 4 Medan tahun pelajaran 2014/2015 hanya sekitar 50\% siswa yang dapat 
dikategorikan lulus, dengan standar ketuntasan minimal mata pelajaran Alat Ukur 75. Rata-rata hasil belajar yang diperoleh siswa dalam ujian akhir semester untuk pelajaran Alat Ukur masih jauh dibawah KKM, Dapat dikatakan bahwa hal tersebut tidak sesuai dengan yang diharapkan.

Budimansyah (dalam Thamrin 2007) mengemukakan bahwa sesulit apapun materi pelajaran, apabila disampaikan dalam suasana menyenangkan maka pelajaran tersebut akan mudah dipahami. Sebaliknya, walau materi pelajaran tidak terlalu sulit untuk dipelajari, namun bila suasana belajar membosankan, tidak menarik dan belajar dibawah tekanan, maka pelajaran akan sulit dipahami. Atas dasar pemikiran tersebut, agar siswa mudah memahami materi ajar dan terjadi kegiatan yang efektif, mereka harus belajar dalam suana yang menyenangkan, penuh daya tarik dan motivasi penuh, sehingga tercapai tujuan yang diharapkan.

Sekolah sebagai lembaga pendidikan formal dituntut mampu memberikan pembelajaran bermutu kepada siswa. Dalam hal ini, seorang guru dituntut berperan aktif dalam menciptakan proses belajar mengajar yang efektif. Pembelajaran akan efektif jika siswa aktif terlibat dalam pembelajaran. Menurut Slameto (2003), pembelajaran selama ini berpusat pada guru (teacher center) dimana guru biasa mengajar dengan metode ceramah, sehingga siswa bosan, mengantuk, pasif, dan hanya mencatat saja. Siswa tidak dituntut berperan aktif dalam proses belajar mengajar, sehingga pembelajaran tidak efektif.

Dalam proses belajar mengajar kehadiran media pembelajaran mempunyai arti yang cukup penting. Dengan Model pembelajaran multimedia interaktif (MMI) diartikan pembelajaran dapat digunakan untuk menyalurkan pesan (message), merangsang pikiran, perasaan, perhatian dan kemauan siswa sehingga dapat mendorong proses belajar. Diharapkan dengan multimedia interaktif (MMI) dapat menjadikan kualitas pembelajaran menjadi efektif sehingga keaktifan dan motivasi belajar siswa meningkat sehingga dapat meningkatkan hasil belajar siswa SMK. Karena dalam kegiatan tersebut ketidakjelasan bahan yang disampaikan dapat dibantu dengan menghadirkan media sebagai perantara. Kerumitan materi pelajaran yang akan disampaikan kepada anak didik dapat disederhanakan, bahkan keabstrakan materi pelajaran dapat dikonkretkan dengan kehadiran media sehingga anak didik lebih mudah mencerna materi pelajaran yang disampaikan. Untuk itu guru dituntut harus mempunyai media pembelajaran yang dapat menarik minat siswa dalam belajar.

Gagne (dalam Dahar :1989) mendefinisikan belajar sebagai sebuah proses dimana suatu organisme berubah perilakunya sebagai akibat dari pengalaman, dengan demikian apa yang dikemukakan Gagne tersebut mengandung makna bahwa belajar menyangkut kepada perubahan diri yang memerlukan waktu. Bruner (dalam Dahar, 1991:101), belajar melibatkan tiga proses yang berlangsung hampir bersamaan. Ketiga proses itu ialah (1) memperoleh informasi baru, (2) transformasi informasi, dan (3) menguji relevansi dan ketepatan pengetahuan.

Sardiman (2008) menyatakan bahwa aktivitas belajar adalah segala kegiatan yang dilakukan dalam proses interaksi (guru dan siswa) dalam rangka mencapai tujuan belajar. Aktivitas yang dimaksudkan disini penekanannya adalah pada siswa, sebab dengan adanya aktivitas siswa dalam proses pembelajaran terciptalah situasi belajar aktif. Sudjana dan Suwariyah (1991) menyatakan bahwa "aktivitas belajar siswa mencakup dua aspek yang tidak dapat terpisahkan, yakni aktivitas mental (emosional - intelektual sosial) dan aktivitas motorik (gerak fisik)". Kedua aspek tersebut berkaitan satu sama lain, saling mengisi dan menentukan. Oleh sebab itu optimalnya cara belajar siswa aktif bukan hanya dilihat dari gerakan motoriknya saja tetapi juga kegiatan mental siswa.

Djamarah (2008) membagi beberapa aktivitas belajar sebagai berikut :1) mendengarkan, 2) memandang, 3) meraba, membau dan mencicip/mengecap, 4) menulis atau mencatat, 5) membaca, 6) membuat ikhtisar atau ringkasan dan menggarisbawahi, 7) mengamati tabel - tabel, diagram - diagram dan bagan - bagan, 8) menyusun paper atau kertas kerja, 9) mengingat, 10) berpikir, 11) praktek atau latihan. Diedrich (dalam Sardiman 2000) membuat suatu daftar yang berisi 177 macam kegiatan siswa yang antara lain dapat digolongkan sebagai berikut:

1. Visual activities, yang termasuk di dalamnya misalnya, membaca, memperhatikan gambar demonstrasi, percobaan, pekerjaan orang lain.

2. Oral activities, seperti: menyatakan merumuskan, bertanya, memberi saran, 
mengeluarkan pendapat, mengadakan wawancara, diskusi, interupsi.

3. Listening activities, sebagai contoh, mendengarkan: uraian, percakapan, diskusi, musik, pidato.

4. Writing activities, seperti misalnya menulis cerita, karangan, laporan, angket, menyalin.

5. Drawing activities, misalnya: menggambar, membuat grafik, peta, diagram.

6. Motor activities, yang termasuk di dalamnya antara lain: melakukan percobaan, membuat konstruksi, model mereparasi, bermain, berkebun, berkebun, beternak.

7. Mental activities, sebagai contoh misalnya: menanggap, mengingat, memecahkan soal, menganalisa, melihat hubungan, mengambil keputusan.

8. Emotional aktivities, seperti misalnya, menaruh minat, merasa bosan, gembira, bersemangat, bergairah, berani, tenang, gugup.

Jadi dengan klasifikasi aktivitas seperti uraian di atas, menunjukkan bahwa aktivitas belajar siswa cukup kompleks dan bervariasi. Kalau berbagai macam kegiatan tersebut dapat diciptakan dalam kegiatan belajar mengajar, tentu akan dinamis, tidak membosankan dan benar - benar menjadi aktivitas belajar yang maksimal. Seperti yang dikemukakan oleh Darnati (2001) "belajar aktif adalah belajar dimana siswa lebih berpatisipasi aktif sehingga kegiatan siswa dalam belajar jauh lebih dominan daripada kegiatan guru dalam mengajar".

Belajar merupakan suatu proses perubahan tingkah laku sebagai hasil interaksi individu dengan lingkungannya dalam memenuhi kebutuhan hidupnya (Sugihartono dkk,2007:74). Sedangkan menurut Moh. Surya dalam bukunya Sri Rumini dkk (1993:59) Belajar adalah suatu proses usaha yang dilakukan individu untuk memperoleh suatu perubahan tingkah laku yang baru secara keseluruhan, sebagai hasil pengalaman individu itu sendiri dalam diri seseorang karena Opengalaman. Menurut Nasution yang dikutip Sugihartono dkk (2007:80) Pembelajaran adalah suatu aktivitas mengorganisasi atau mengatur lingkungan sebaik-baiknya dan menghubungkannya dengan anak didik sehingga terjadi proses belajar. Lingkungan dalam pengertian ini tidak hanya ruang belajar, tetapi juga meliputi guru, alat peraga, perpustakaan, laboratorium, dan sebagainya yang relevan dengan kegiatan belajar siswa. Sedangkan menurut Oemar Hamalik (2005:57) pembelajaran adalah suatu kombinasi yang tersusun meliputi unsur-unsur manusiawi, material, fasilitas, perlengkapan, dan prosedur yang saling mempengaruhi mencapai tujuan pembelajaran.

Belajar merupakan suatu proses perubahan tingkah laku sebagai hasil interaksi individu dengan lingkungannya dalam memenuhi kebutuhan hidupnya (Sugihartono dkk,2007:74). Sedangkan menurut Moh. Surya dalam bukunya Sri Rumini dkk (1993:59) Belajar adalah suatu proses usaha yang dilakukan individu untuk memperoleh suatu perubahan tingkah laku yang baru secara keseluruhan, sebagai hasil pengalaman individu itu sendiri dalam diri seseorang karena pengalaman Menurut pendapat Nana Sudjana (1987:28) belajar bukan sekedar menghafal atau mengingat melainkan suatu proes aktif, yaitu proses mereaksikan tentang semua situasi yang ada di sekitar individu. Belajar ditandai dengan adanya perubahan pada diri seseorang yang dapat berupa pengetahuan, pemahaman, sikap, tingkah laku, ketrampilan, kecakapan, dan kemampuannya. Perubahan tersebut sifatnya relatif menetap, perubahan tersebut diperoleh melalui berbagai pengalaman dan latihan yang dilakukan selama hidupnya. Sejalan dengan pendapat tersebut dapat dinyatakan bahwa belajar mengajar merupakan interaksi atau hubungan timbal balik antara siswa dengan guru sebagai fasilitator belajar, antar sesama siswa, dan antara siswa dengan lingkungannya, sehingga diperoleh suatu pengalaman nyata dalam kehidupannya.

Hasil belajar berkaitan dengan pencapaian dalam memperoleh kemampuan sesuai dengan tujuan khusus yang direncanakan (Sanjaya, 2010:13). Hasil belajar adalah kemampuan yang dimiliki siswa setelah ia menerima pengalaman belajarnya. Howard Kingsley dalam Sudjana (2001:22) membagi tiga macam hasil belajar, yaitu (a) keterampilan dan kebiasaan, (b) pengetahuan dan pengertian, (c) sikap dan cita-cita, masingmasing jenish hasil belajar dapat diisi dengan bahan yang telah ditetapkan dalam kurikulum. Hasil belajar siswa pada hakikatnya adalah perubahan mencakup bidang kognitif, afektif dan psikomotoris yang berorientasi pada proses belajar mengajar yang dialami siswa. 
Hamalik (2004:30) mengatakan hasil belajar akan tampak pada setiap perubahan pada aspek-aspek tersebut. Adapun aspekaspek itu adalah: (a) pengetahuan, (b) pengertian, (c) kebiasaan, (d) keterampilan, (e) apresiasi, (f) emosional, (h) hubungan sosoial, (i) jasmani, (j) etis atau budi pekerti, dan (k) sikap.

Menurut Jenkins dan Unwin (Uno, 2011: 17) yang mengatakan bahwa hasil belajar adalah pernyataan yang menunjukkan tentang apa yang mungkin dikerjakan siswa sebagai hasil dari kegiatan belajarnya. Jadi hasil belajar merupakan pengalaman-pengalaman belajar yang diperoleh siswa dalam bentuk kemampuan-kemampuan tertentu. Pendapat lain tentang hasil belajar dikemukakan oleh Briggs (dalam Taruh, 2003: 17) yang mengatakan bahwa hasil belajar adalah seluruh kecakapan dan hasil yang dicapai melalui proses belajar mengajar di sekolah yang dinyatakan dengan angka-angka atau nilai-nilai berdasarkan tes hasil belajar. Hal ini senada dengan Rasyid (2008: 9) yang berpendapat bahwa jika ditinjau dari segi proses pengukurannya, kemampuan seseorang dapat dinyatakan dengan angka. Dengan demikian, hasil belajar siswa dapat diperoleh guru dengan terlebih dahulu memberikan seperangkat tes kepada siswa untuk menjawabnya. Hasil tes belajar siswa tersebut akan memberikan gambaran informasi tentang kemampuan dan penguasaan kompetensi siswa pada suatu materi pelajaran yang kemudian dikonversi dalam bentuk angkaangka. Bloom dan Kratwohl (dalam Muhammad Usman, 2008: 29) bahwa hasil belajar merupakan perubahan tingkah laku yang secara umum dapat dikelompokkan ke dalam tiga kategori yaitu ranah kognitif, afektif, dan psikomotor.

Sudjana (2009) menyatakan bahwa "hasil belajar adalah kemampuan - kemampuan yang dimiliki siswa setelah menerima pengalaman belajarnya".

Kemudian Abdurrahman menyatakan bahwa: Hasil belajar adalah kemampuan yang diperoleh anak setelah melalui kegiatan belajar. Belajar itu sendiri merupakan suatu proses dari seseorang yang berusaha untuk memperoleh suatu bentuk perubahan perilaku yang relatif menetap. Dalam kegiatan belajar yang terperogram dan terkontrol yang disebut kegiatan pembelajaran atau kegiatan instruksional, tujuan belajar telah ditetapkan lebih dahulu oleh guru. Anak yang berhasil dalam belajar ialah yang berhasil mencapai tujuan - tujuan pembelajaran atau tujuan - tujuan instruksional.

Untuk melihat hasil belajar dilakukan suatu penilaian terhadap siswa yang bertujuan untuk mengetahui apakah siswa telah menguasai materi atau tidak. Sudjana (2009) mengatakan bahwa "penilaian hasil belajar adalah proses pemberian nilai terhadap hasil belajar yang dicapai siswa dengan kriteria tertentu". Dalam penilaian, peranan tujuan instruksional yang berisi rumusan kemampuan dan tingkah laku yang diinginkan dikuasai siswa menjadi unsur penting sebagai dasar dan acuan penilaian.

Pengukuran adalah membandingkan sesuatu dengan besaran standar (Sudji Munadi, 1988:61). Pengukuran dalam arti yang luas adalah membandingkan suatu besaran dengan besaran standar (Taufik Rochim dan Soetarto,1980:90). Alat yang digunakan sebagai pembanding disebut alat ukur (Taufik Rochim dan Soetarto,1980: 92).

Dewey (dalam Davies terjemahan Dimyati dan Mudjiono 2006) menekankan bahwa oleh karena belajar menyangkut apa yang harus dikerjakan murid - murid untuk dirinya sendiri, maka inisiatif harus datang dari murid - murid sendiri. Guru adalah pembimbing dan pengarah, yang mengemudikan perahu, tetapi tenaga untuk menggerakan perahu tersebut haruslah berasal dari murid yang belajar.

Media merupakan segala sesuatu yang dapat digunakan untuk menyalurkan pesan dari pengirim kepada penerima sehingga dapat merangsang pikiran, perasaan, perhatian, dan minat siswa yang menjurus kearah terjadinya proses belajar (Arsyad, 2007). Menurut Djamarah dan Zain (2002) "media adalah alat bantu apa saja yang dapat dijadikan sebagai penyalur pesan guna mencapai tujuan pembelajaran". Dengan adanya alat bantu dalam proses belajar mengajar yang berfungsi menyampaikan pesan-pesan dari materi pelajaran yang diberikan oleh guru kepada peserta didik maka materi pelajaran yang sukar untuk dicerna menjadi mudah untuk dipahami.

Sudjana (dalam Djamarah dan Zain 2002) merumuskan fungsi media pengajaran menjadi enam kategori, sebagai berikut: (1) Penggunaan media dalam proses belajar mengajar bukan merupakan fungsi tambahan, tetapi mempunyai fungsi sendiri sebagai alat bantu untuk mewujudkan situasi belajar 
mengajar yang efektif; (2) Penggunaan media pengajaran merupakan bagian yang integral dari keseluruhan situasi mengajar, jadi setiap guru wajib mengembangkannya; (3) Penggunaan media pengajaran harus melihat kepada tujuan dan materi pelajaran; (4) Penggunaan media dalam pengajaran bukan semata-mata alat hiburan untuk melengkapi proses belajar mengajar supaya lebih menarik perhatian siswa; (5) Penggunaan media dalam pengajaran lebih diutamakan untuk mempercepat proses belajar mengajar dan membantu siswa dalam menangkap pengertian yang diberikan guru; (6) Penggunaan media dalam pengajaran diutamakan untuk mempertinggi mutu belajar mengajar sehingga hasil belajar yang dicapai siswa akan tahan lama diingat siswa; (7) Menurut Sudjana dan Rivai (dalam Djamarah dan Zain 2002) ada beberapa faktor pertimbangan sebuah media digunakan dalam proses pembelajaran, antara lain: (1) Ketepatannya dengan tujuan pembelajaran; (2) Dukungan terhadap bahan pembelajaran; (3) Kemudahan memperoleh media; (4) Keterampilan dalam menggunakannya; (5) Tersedia waktu untuk menggunakannya; (6) Sesuai taraf berfikir siswa

Sutopo (2003) menjelaskan bahwa multimedia terbagi menjadi dua kategori, yaitu multimedia linier dan multimedia interaktif. Multimedia linier adalah suatu multimedia yang tidak dilengkapi dengan alat pengontrol apapun yang dapat dioperasikan oleh pengguna. Multimedia ini berjalan sekuensial (berurutan), contohnya televisi dan film. Multimedia interaktif adalah suatu multimedia yang dilengkapi dengan alat pengontrol yang dapat dioperasikan oleh pengguna, sehingga pengguna dapat memilih apa yang dikehendaki untuk proses selanjutnya. Contoh multimedia interaktif adalah multimedia pembelajaran.

Berdasarkan uraian di atas, maka hipotesis tindakan dalam penelitian ini adalah sebagai berikut: (1) Proses pembelajaran dengan menggunakan Multimedia Interaktif dapat meningkatkan aktivitas siswa pada pelajaran Alat Ukur dikelas X SMK AlWashliyah 4 Medan; (2) Proses pembelajaran dengan menggunakan Multimedia Interaktif dapat meningkatkan hasil belajar siswa pada pelajaran Alat Ukur dikelas X SMK AlWashliyah 4 Medan.

\section{METODE}

Penelitian dilaksanakan di SMK AlWashliyah 4 Medan. Penelitian ini dilakukan dengan 2 siklus, siklus I dilaksanakan selama 1 minggu dan siklus II dilaksanakan selama 1 minggu. Subjek dalam penelitian ini adalah siswa kelas X SMK Al-Washliyah 4 Medan Tahun Ajaran 2015/2016. Jumlah siswa yang menjadi subjek penelitian sebanyak 32 orang siswa. Objek penelitian ini adalah pembelajaran menggunakan Multimedia Interaktif untuk meningkatkan aktivitas dan hasil belajar siswa pada pelajaran Alat Ukur dikelas X SMK AlWashliyah 4 Medan Tahun Ajaran 2015/2016.

Secara umum desain pembelajaran mengikuti langkah - langkah penelitian tindakan kelas (PTK), yang dilaksanakan dalam 2 siklus dimana setiap siklus terdiri atas 2 kali pertemuan dan masing - masing siklus terdiri dari 4 tahap sebagai berikut : Perencanaan Tindakan, Pelaksanaan Tindakan, Observasi, Evaluasi dan Refleksi

Perencanaan

Pada tahap ini peneliti dan guru bekerja sama mempersiapkan : Menganalisis kurikulum untuk mengetehui kompetensi dasar yang akan disampaikan kepada siswa, selanjutnya menyiapkan perangkat pembelajaran berbentuk silabus dan rencana pelaksanaan pembelajaran (RPP) sesuai dengan pokok bahasan Alat Ukur yang akan diajarkan; (2) Merencanakan skenario tindakan dan tes yang berhubungan dengan materi yang akan diajarkan; (3) Menyediakan media pembelajaran dalam rangka implementasi penelitian ini; (4) Merencanakan lembar observasi untuk mengetahui bagaimana kondisi proses belajar mengajar dengan menggunakan Multimedia Interaktif.

Pelaksanaan Tindakan

Tahap pelaksanaan dilakukan di dalam kelas dengan melakukan kegiatan pembelajaran sesuai dengan rencana pelaksanaan pembelajaran (RPP) yang telah disediakan. Pada tahap ini guru langsung memainkan perannya dalam mengkordinir siswa dengan membagi seluruh siswa menjadi 4 kelompok dan membimbing kelompok belajarnya. Pelaksanaan tindakan direncanakan dalam 2 siklus dan tiap siklus diselesaikan dalam 2 kali tatap muka.

Guna mengoptimalkan penggunaan media, maka pembelajaran didukung dengan beberapa metode, diantaranya metode ceramah, demontrasi, tanya jawab dan diskusi. Pada fase ini peneliti berperan sebagai pengamat dan 
peneliti bertindak juga sebagai pengajar jika diperlukan dan didampingi rekan sejawat sebagai observer. Dan sebelum tindakan dilaksanakan, pembelajaran telah dilakukan penugasan.

Pengamatan atau Observasi

Observasi dilakukan pada saat proses pembelajaran berlangsung. Observasi ini untuk mengetahui aktivitas siswa selama proses belajar mengajar berlangsung. Dalam hal ini yang bertindak sebagai observer adalah guru bidang studi.

Evaluasi dan Refleksi

Evaluasi keseluruhan siklus dilakukan saat kegiatan belajar telah dilaksanakan seluruhnya dan diakhiri dengan evaluasi hasil belajar siswa. Selanjutnya refleksi dilakukan berdasarkan hasil analisis data perolehan tes dan observasi yang dilakukan pada saat proses pembelajaran berlangsung. Kesemua informasi ini akan dikaji bersama oleh peneliti dan observer, maka akan diperoleh gambaran tentang hasil penggunaan Multimedia Interaktif berupa video pembelajaran Alat Ukur. Kemudian refleksi ini dilakukan sebagai dasar menentukan tindakan perbaikan untuk tahap perencanaan pada siklus berikutnya.

Penelitian tindakan kelas ini dikatakan berhasil apabila:

a. Aktivitas belajar seluruh siswa mencapai $75 \%$ dalam kemampuan menjawab pertanyaan guru, berani menanggapi dan mengemukakan pendapat tentang jawaban siswa yang lain, berani dan mampu untuk bertanya, aktif dalam mengerjakan tugas kelompoknya.

b. Penyelesaian tugas kelompok sesuai dengan waktu yang telah disediakan.

c. Meningkatnya nilai ulangan PTK pada tiap akhir siklus setelah menggunakan Multimedia Interaktif.

Untuk memperoleh data yang dibutuhkan sebagai bahan penganalisaan dalam suatu penelitian perlu ditetapkan alat pengumpul data. Peneliti dalam hal ini menggunakan metode pengumpul data, yaitu tes dan observasi.

Tes yang digunakan dalam penelitian ini adalah ulangan formatif yang dilakukan pada akhir siklus guna memperoleh data yang diinginkan dan untuk mendapatkan gambaran tentang kemampuan seseorang atau sekelompok orang. Dalam hal ini tes berupa soal - soal uraian terbatas (essay) yang diambil dari buku pegangan guru yang selalu digunakan sebagai sumber soal-soal pada mata pelajaran Alat Ukur. Dengan indikator, siswa yang dikatakan tuntas belajar apabila memperoleh nilai $\geq 75$. Dan batas ketuntasan belajar siswa secara klasikal tercapai bila $80 \%$ siswa memperoleh nilai $\geq 75$ dalam memahami materi yang telah diberikan.

Cara penilaian tes

$$
\text { Nilai }=
$$

$\frac{\text { jumlahskoryangdiperdeh }}{\text { skortotal }} \times 100$

Kriteria penilaian

$$
\begin{aligned}
& 0-74=\text { Belum kompeten } \\
& 75-100 \quad=\text { Kompeten } \\
& \text { Data yang dikumpulkan pada setiap }
\end{aligned}
$$
kegiatan observasi dari pelaksanaan siklus penelitian dianalisis secara deskriptif.

a. Hasil belajar : dengan menganalisis nilai ulangan PTK. Dengan menggunakan kriteria yang ditetapkan dalam kurikulum, yakni siswa dinyatakan tuntas belajar secara individual bila telah memperoleh skor minimal 70\% dari skor total dan ketuntasan klasikal tercapai bila di kelas tersebut terdapat $80 \%$ siswa tuntas belajar.

b. Aktivitas siswa dalam proses belajar mengajar Alat Ukur : dengan menganalisis tingkat keaktifan siswa dalam proses belajar mengajar Alat Ukur dengan deskritif presentase secara kuantitatif.

\section{HASIL DAN PEMBAHASAN \\ Hasil}

Dalam aspek aktifitas siswa hasil observasi pada siklus pertama dengan perolehan rata-rata skor 46,14 pada kategori cukup aktif. Dalam hal ini aspek aktifitas siswa tergolong kurang, yang mana aspek Aktifitas siswa dikatakan berhasil jika mencapai lebih dari atau sama dengan $75 \%$. Fokus pengamatan observer terhadap aktifitas siswa pada penelitian ini ada tujuh indikator yaitu : (1) Visual, (2) Oral, (3) Listening, (4) Writing, (5) Drawing,(6)Motor, (7) Mental, dan (8) Emotional.

Adapun penjelasan dari rendahnya perolehan rata-rata skor antara lain :

a) Indikator 1:

Siswa mendengarkan penjelasan guru dengan baik namun terkadang pada setiap pembelajaran, ini tidak seperti yang biasa yang mana ada petunjuk dan ketentuan yang harus diikuti.

b) Indikator2 : 
Siswa belum dapat berperan aktif seperti berani bertanya kepada guru maupun mengeluarkan pendapat masih ada rasa takut siswa untuk mengemukakan pendapat. Hal ini dikarenakan pembelajaran belum dihubungkan dengan kehidupan sehari-hari sehingga siswa masih merasa asing akan pokok bahasan.

c) Indikator3:

Pada indikator ini hanya sebahagian siswa berpartisipasi aktif mendengarkan arahan guru.

d) Indikator4 :

Masih ada terlihat siswa yang kebingungan akan mengerjakan atau menulis apa. Hal ini terjadi karna siswa tersebut belum memahami perintah dan arahan dari guru maupun dari soal yang dikerjakan.

e) Indikator 5 :

Siswa yang mengerjakan pengukuran hanya sekedar mengerjakan saja tanpa mengikuti prosedur kerja yang ada.

f) Indikator6 :

Siswa belum memahami tujuan pengukuran sehingga belum muncul rasa semangat untuk mengerjakannya.

g) Indikator7 :

Siswa kesulitan memahami penjelasan guru tanpa bantuan visualisasi dalam mengerjakan pengukuran.

Observasi aspek aktifitas siswa selama proses belajar mengajar pada siklus I dapat dilihat pada Tabel 1

Tabel 1. Perolehan Persentase Skor Aspek Aktivitas Siswa Dalam Proses Belajar Mengajar Siklus ke-1

\begin{tabular}{|c|c|c|c|c|}
\hline Indikator & Skor Perolehan & Skor Ideal & Persentase & Ket. \\
\hline 1 & 122 & 256 & 47.66 & Cukup \\
\hline 2 & 132 & 256 & 51.56 & Cukup \\
\hline 3 & 140 & 256 & 54.69 & Cukup \\
\hline 4 & 114 & 256 & 44.53 & Cukup \\
\hline 5 & 104 & 256 & 40.63 & Cukup \\
\hline 6 & 105 & 256 & 41.02 & Cukup \\
\hline 7 & 119 & 256 & 46.48 & Cukup \\
\hline 8 & 109 & 256 & 42.58 & Cukup \\
\hline Rata-rata & 118.125 & & 46.14 & Cukup \\
\hline
\end{tabular}

Keterangan:

Indikator1 adalah Visual

Indikator2 adalah Oral

Indikator3 adalah Listening

Indikator4 adalah Writing

Indikator5 adalah Drawing

Indikator6 adalah Motor

Indikator7 adalah Mental

Indikator8 adalah Emotional

\section{Refleksi I (Reflecting)}

Berdasarkan hasil yang diperoleh pada siklus pertama aktifitas siswa dalam proses belajar mengajar masih rendah, metode ceramah yang digunakan dalam pembelajaran membuat siswa jenuh. Siswa hanya mendengarkan penjelasan guru,hal ini berarti Aktifitas belajar tergolong pada kategori cukup. Kategori ini disebabkan oleh beberapa aspek Aktifitas belajar siswa pada siklus I masih bertaraf lemah. Aspek-aspek tersebut antara lain aspek Oral, Motor,Emotional, Writing dan Drawing.(1) aspek Oral siswa pada siklus pertama tidak mau bertanya atau menjawab pertanyaan, siswa hanya berbicara dengan teman semejanya saja. Hal ini terjadi diperkirakan karena siswa bingung akan penjelasan guru yang tergolong monoton, tidak ada visualisasi dari materi yang diajarkan sehingga siswa jenuh. (2) Aspek Motor siswa pada siklus ini siswa tidak memiliki aktivitas yang memadai, siswa mencobakan alat ukur dengan bergantian karena jumlah alat yang tidak sebanyak jumlah siswa. Hanya beberapa orang yang aktif melakukan pengukuran. Siswa tidak lagi mengulang proses pengukuran diluar jam pelajarannya. (3) Aspek Emotional siswa pada siklus ini dipengaruhi kondisi pada kedua aspek diatas seperti yang terlihat pada saat sesi diskusi di kelas dalam melakukan pengukuran terlihat hanya beberapa orang saja yang turut ikut andil misalnya dalam melakukan prosedur dari percobaan yang dilakukan atau menjawab pertanyaan. (4) Aspek Writing dan (5) Drawing siswa pada siklus pertama terlihat siswa kebingungan 
menulis penjelasan guru, sulit menggambarkan alat ukur dan hasil pengukuran karena tidak ada media visualisasi yang baik. Untuk mengatasi kendala pada siklus pertama ini peneliti mencoba menggunakan multimedia pembelajaran interaktif, dimana peneliti menggunakan visualisasi pengukuran jangka sorong dan mikrometer skrup macromedia flash, yang dioperasionalkan dengan laptop dan di proyeksikan menggunakan infokus. Diharapkan dengan menggunakan multimedia ini siswa dapat melakukan aktivitas visual, menulis dan menggambar dengan baik. Pembelajaran dirancang dengan pembelajaran kelompok agar terjadi interaksi sesama siswa baik mencoba mengukur maupun berdiskusi atas kesulitan pembelajaran.

\section{Data Aktivitas Kelompok Siswa Dalam Proses Pembelajaran Siklus II}

Dalamaspek aktivitas siswa hasil observasi pada siklus kedua dengan perolehan rata-rata skor 202,125 pada skor ideal 256 . Sedangkan perolehan persentasi nilai rata-rata aspek Aktifitas siswa adalah 78,96\% pada kategori aktif. Dalam hal ini aspek aktifitas siswa tergolong sudah aktif, yang mana aspek Aktifitas siswa dikatakan berhasi jika mencapai lebih dari atau sama dengan $75 \%$. Fokus pengamatan observer terhadap akti fitas siswa pada penelitian ini ada delapan yaitu : (1) Visual, (2) Oral, (3) Listening, (4) Writing, , (5) Drawing, (6) Motor, (7) Mental, dan (8) Emotional.

Data aktivitas kelompok siswa dalam proses pembelajaran diperoleh melalui lembar observasi. Observasi dilakukan oleh seorang guru yang bertugas sebagai kolaboratif atau pengamat aktivitas kelompok siswa. Guru pengamat menggunakan lembar observasi sistematik yang telah dikembangkan sesuai dengan tahapan pembelajaran. Aktivitas kelompok siswa yang diamati mencakup 7 aspek pengamatan dengan indikator, yaitu :

Adapun penjelasan dari perolehan ratarata skor antara lain :

a) Indikator 1 :

Siswa mendengarkan penjelasan guru dengan baik, meski masih ada siswa yang masih berbicara dengan teman dalam kelompok, tetapi mereka antusias mendengarkan penjelasan guru.

b) Indikator 2 :

Siswa dapat berperan aktif seperti berani bertanya kepada guru maupun mengeluarkan pendapat masih ada rasa takut siswa untuk mengemukakan pendapat. Hal ini dikarenakan pembelajaran lebih menarik dengan menggunakan media visualisasi yang juga dapat melibatkan siswa dalam proses pembelajaran.

c) Indikator3:

Pada indikator ini siswa berpartisipasi aktif mendengarkan arahan guru dengan bantuan media visualisasi pengukuran.

d) Indikator4 : siswa mampu mengikuti arahan dari guru maupun dari soal yang dikerjakan.

e) Indikator 5 :

Siswa yang mengerjakan pengukuran sesuai dengan petunjuk dan arahan berdasarkan visualisasi media pembelajaran.

f) Indikator 6 :

Siswa sudah memahami tujuan pengukuran sehingga muncul rasa semangat untuk mengerjakannya.

g) Indikator7 :

Siswa memahami penjelasan guru dengan bantuan visualisasi dalam mengerjakan pengukuran.

Observasi aspek aktifitas siswa selama proses belajar mengajar pada siklus II dapat dilihat pada Tabel 2 .

Tabel 2. Perolehan Persentase Skor Aspek Aktivitas Siswa Dalam Proses Belajar Mengajar Siklus II

\begin{tabular}{|c|c|c|c|c|}
\hline Indikator & Skor Perolehan & Skor Ideal & Persentase & Ket. \\
\hline 1 & 221 & 256 & 86.33 & Sangat Aktif \\
\hline 2 & 212 & 256 & 82.81 & Sangat Aktif \\
\hline 3 & 207 & 256 & 80.86 & Sangat Aktif \\
\hline 4 & 227 & 256 & 88.67 & Sangat Aktif \\
\hline 5 & 190 & 256 & 74.22 & Aktif \\
\hline 6 & 214 & 256 & 83.59 & Sangat Aktif \\
\hline 7 & 180 & 256 & 70.31 & Aktif \\
\hline 8 & 166 & 256 & 64.84 & Aktif \\
\hline
\end{tabular}




\begin{tabular}{|c|c|c|c|c|}
\hline Indikator & Skor Perolehan & Skor Ideal & Persentase & Ket. \\
Rata-rata & 202.125 & & 78.96 & Aktif \\
\hline
\end{tabular}

Keterangan:

Indikator1 adalah Visual

Indikator2 dalah Oral

Indikator3 adalah Listening.

Indikator4 adalah Writing.

Indikator5 adalah Drawing

Indikator6 adalah Motor.

Indikator7 adalah Mental

Indikator8 adalah Emotional
Data aktivitas kelompok siswa dalam proses pembelajaran diperoleh melalui lembar observasi. Observasi dilakukan oleh seorang guru yang bertugas sebagai kolaboratif atau pengamat aktivitas kelompok siswa. Guru pengamat menggunakan lembar observasi sistematik yang telah dikembangkan sesuai dengan tahapan pembelajaran.. Aktivitas kelompok siswa yang diamati mencakup 8 aspek pengamatan aktivitas, yaitu :

Tabel 3. Distribusi Aktivitas Kelompok Siswa Dalam Proses Pembelajaran Menggunakan Metode Eksperimen Siklus II

\begin{tabular}{|c|c|c|c|c|c|c|c|}
\hline \multirow{2}{*}{$\begin{array}{c}\text { Nomor } \\
\text { Indikator }\end{array}$} & \multicolumn{5}{|c|}{ Kelompok } & \multirow{2}{*}{} & \multirow{2}{*}{ Ket. } \\
\hline & I & II & III & IV & Skor & Nilai & Ket. \\
\hline 1 & 55 & 56 & 54 & 56 & 221 & 86.33 & Sangat Aktif \\
\hline 2 & 54 & 51 & 53 & 54 & 212 & 82.81 & Sangat Aktif \\
\hline 3 & 51 & 53 & 53 & 50 & 207 & 80.86 & Sangat Aktif \\
\hline 4 & 57 & 59 & 55 & 56 & 227 & 88.67 & Sangat Aktif \\
\hline 5 & 47 & 46 & 48 & 49 & 190 & 74.22 & Aktif \\
\hline 6 & 53 & 51 & 55 & 55 & 214 & 83.59 & Sangat Aktif \\
\hline 7 & 44 & 50 & 45 & 41 & 180 & 70.31 & Aktif \\
\hline 8 & 33 & 38 & 47 & 48 & 166 & 64.84 & Cukup Aktif \\
\hline Jumlah & 394 & 404 & 410 & 409 & & & \\
\hline Nilai & 76.95 & 78.91 & 80.08 & 79.88 & & & \\
\hline Ket. & Aktif & Aktif & Sangat Aktif & Aktif & & & \\
\hline
\end{tabular}

Keterangan skor:

Skor 21-40 : Kurang Aktif

Skor 41-60 : Cukup Aktif

Skor 61-80 : Aktif

Skor 81-100 : sangat Aktif

Dari Tabel 4.4. diatas terlihat bahwa perolehan persentase rata-rata kelompok I adalah $76,95 \%$ tergolong aktif, kelompok II adalah $78,91 \%$ tergolong aktif, kelompok III adalah $80,08 \%$ tergolong sangat aktif dan kelompok IV adalah $79,88 \%$ tergolong aktif. Seluruh kelompok telah aktif mengikuti pembelajaran, hal ini menunjukan keberhasilan proses dalam siklus kedua dimana aktivitas siswa sudah lebih dari $75 \%$.

Secara rata-rat ada peningkatan sebesar $32.81 \%$, yaitu dari $46,14 \%$ pada siklus pertama menjadi $78,96 \%$ pada siklus kedua dan dapat dilihat pada Tabel 4.

Tabel 4. Peningkatan Persentase Skor Rata-rata Kelompok Aspek Aktivitas Siswa

Dalam Proses Belajar Mengajar.

\begin{tabular}{|c|c|c|c|c|c|c|}
\hline \multirow[t]{2}{*}{ Aspek } & \multicolumn{2}{|c|}{ Perolehan Siklus I } & \multicolumn{2}{|c|}{ Perolehan Siklus II } & \multirow{2}{*}{$\begin{array}{l}\text { Skor } \\
\text { Ideal }\end{array}$} & \multirow{2}{*}{$\begin{array}{c}\text { Persen } \\
\text { Gain }\end{array}$} \\
\hline & Nilai Skor & Persentase & Nilai Skor & Persentase & & \\
\hline 1 & 122 & 47.66 & 221 & 86.33 & 256 & 38.67 \\
\hline 2 & 132 & 51.56 & 212 & 82.81 & 256 & 31.25 \\
\hline 3 & 140 & 54.69 & 207 & 80.86 & 256 & 26.17 \\
\hline 4 & 114 & 44.53 & 227 & 88.67 & 256 & 44.14 \\
\hline 5 & 104 & 40.63 & 190 & 74.22 & 256 & 33.59 \\
\hline 6 & 105 & 41.02 & 214 & 83.59 & 256 & 42.58 \\
\hline
\end{tabular}




\begin{tabular}{|c|c|c|c|c|c|c|}
\hline \multirow{2}{*}{ Aspek } & \multicolumn{2}{|c|}{ Perolehan Siklus I } & \multicolumn{2}{c|}{ Perolehan Siklus II } & Skor & Persen \\
& Nilai Skor & Persentase & Nilai Skor & Persentase & Ideal & Gain \\
\cline { 2 - 4 } & 119 & 46.48 & 180 & 70.31 & 256 & 23.83 \\
\hline 8 & 109 & 42.58 & 166 & 64.84 & 256 & 22.27 \\
\hline Rata-rata & 118.125 & 46.14 & 202.125 & 78.96 & 256 & 32.81 \\
\hline
\end{tabular}

Hasil penelitian menunjukkan bahwa pembelajaran Alat Ukur dengan menggunakan Multimedia interaktif efektif digunakan untuk meningkatkan aktivitas. Secara keseluruhan penelitian menunjukkan adanya peningkatan aktivitas belajar siswa.

Dari Tabel 4. diatas setelah diadakan tes hasil belajar pada akhir pembelajaran siklus kedua, diperoleh hasil penguasaan siswa terhadap materi belajar tergolong baik yaitu dengan skor rata-rata 16,03 dari skor ideal 20 skor atau perolehan nilai rata-rata 80,16 dan siswa yang mencapai ketuntasan belajar 26 orang dari 32 orang siswa atau sebesar $81,25 \%$. Perolehan nilai rata-rata tersebut dapat dijadikan sebagai tolak ukur bahwa pembelajaran sudah memenuhi target dimana lebih dari $75 \%$ siswa telah memenuhi kompetensi.

Dari tabel 4. rata-rata untuk indikator peningkatan hasil belajar secara rata-rata ada peningkatan sebesar $18,91 \%$,yaitu dari $61,25 \%$ pada siklus pertama menjadi $80,16 \%$ pada siklus kedua dan akhir siklus kedua hasil pembelajaran sudah memenuhi harapan, yakni peningkatan hasil belajar siswa secara individu dan dapat dilihat pada Tabel 5.

Tabel 5. Peningkatan Persentase Skor Rata-rata Hasil Belajar Siswa Dalam Proses Belajar Mengajar

\begin{tabular}{|c|c|c|c|c|c|c|}
\hline \multirow{2}{*}{$\begin{array}{c}\text { No. } \\
\text { Absen }\end{array}$} & \multicolumn{2}{|c|}{ Perolehan Siklus I } & \multicolumn{2}{|c|}{ Perolehan Siklus II } & \multirow{2}{*}{$\begin{array}{l}\text { Skor } \\
\text { Ideal }\end{array}$} & \multirow{2}{*}{$\begin{array}{c}\text { Persen } \\
\text { Gain }\end{array}$} \\
\hline & Skor & Nilai & Skor & Nilai & & \\
\hline 1 & 13 & 65 & 17 & 85 & 20 & 20 \\
\hline 2 & 13 & 65 & 18 & 90 & 20 & 25 \\
\hline 3 & 17 & 85 & 17 & 85 & 20 & 0 \\
\hline 4 & 17 & 85 & 18 & 90 & 20 & 5 \\
\hline 5 & 15 & 75 & 16 & 80 & 20 & 5 \\
\hline 6 & 13 & 65 & 15 & 75 & 20 & 10 \\
\hline 7 & 16 & 80 & 16 & 80 & 20 & 0 \\
\hline 8 & 12 & 60 & 16 & 80 & 20 & 20 \\
\hline 9 & 12 & 60 & 15 & 75 & 20 & 15 \\
\hline 10 & 13 & 65 & 13 & 65 & 20 & 0 \\
\hline 11 & 17 & 85 & 17 & 85 & 20 & 0 \\
\hline 12 & 12 & 60 & 17 & 85 & 20 & 25 \\
\hline 13 & 17 & 85 & 18 & 90 & 20 & 5 \\
\hline 14 & 16 & 80 & 16 & 80 & 20 & 0 \\
\hline 15 & 8 & 40 & 13 & 65 & 20 & 25 \\
\hline 16 & 8 & 40 & 15 & 75 & 20 & 35 \\
\hline 17 & 12 & 60 & 17 & 85 & 20 & 25 \\
\hline 18 & 14 & 70 & 18 & 90 & 20 & 20 \\
\hline 19 & 9 & 45 & 17 & 85 & 20 & 40 \\
\hline 20 & 11 & 55 & 18 & 90 & 20 & 35 \\
\hline 21 & 9 & 45 & 15 & 75 & 20 & 30 \\
\hline 22 & 7 & 35 & 18 & 90 & 20 & 55 \\
\hline 23 & 13 & 65 & 16 & 80 & 20 & 15 \\
\hline 24 & 9 & 45 & 15 & 75 & 20 & 30 \\
\hline 25 & 9 & 45 & 18 & 90 & 20 & 45 \\
\hline
\end{tabular}




\begin{tabular}{|c|c|c|c|c|c|c|}
\hline \multirow{2}{*}{$\begin{array}{c}\text { No. } \\
\text { Absen }\end{array}$} & \multicolumn{2}{|c|}{ Perolehan Siklus I } & \multicolumn{2}{|c|}{ Perolehan Siklus II } & \multirow{2}{*}{$\begin{array}{l}\text { Skor } \\
\text { Ideal }\end{array}$} & \multirow{2}{*}{$\begin{array}{c}\text { Persen } \\
\text { Gain }\end{array}$} \\
\hline & Skor & Nilai & Skor & Nilai & & \\
\hline 26 & 12 & 60 & 13 & 65 & 20 & 5 \\
\hline 27 & 13 & 65 & 14 & 70 & 20 & 5 \\
\hline 28 & 9 & 45 & 13 & 65 & 20 & 20 \\
\hline 29 & 15 & 75 & 15 & 75 & 20 & 0 \\
\hline 30 & 13 & 65 & 17 & 85 & 20 & 20 \\
\hline 31 & 8 & 40 & 17 & 85 & 20 & 45 \\
\hline 32 & 10 & 50 & 15 & 75 & 20 & 25 \\
\hline Rata-rata & 12.25 & 61.25 & 16.03 & 80.16 & 20 & 18.91 \\
\hline
\end{tabular}

Untuk mengetahui kategori peningkatan hasil belajar dapat dilihat berdasarkan nilai gain ternormalisasi hasil belajar siswa. Nilai gain ternormalisasi dapat dilihat pada Tabel 6 .

Tabel 6. Deskripsi Data Gain Ternormalisasi Hasil Belajar Siswa

\begin{tabular}{|l|c|c|c|c|c|c|c|}
\hline No & Tes & $\begin{array}{c}\text { Rata- } \\
\text { rata }\end{array}$ & Tuntas & $\begin{array}{c}\text { Tidak } \\
\text { tuntas }\end{array}$ & $\begin{array}{c}\text { Persentase } \\
\text { ketuntasan }\end{array}$ & $\begin{array}{c}\text { Rata-rata Nilai } \\
\text { Gain } \\
\text { Ternormalisasi }\end{array}$ & Ket. \\
\hline 1. & Siklus I & 12,25 & 7 & 27 & 21,87 & 0.31 & Sedang \\
\hline 2. & SiklusII & 16,03 & 26 & 6 & 81,25 & 0.31 & \multicolumn{2}{l}{} \\
\hline \multicolumn{2}{|l|}{ Peningkatan } & 3,78 & 19 & -19 & 61,50 & \multicolumn{2}{l}{} \\
\hline
\end{tabular}

Dari tabel di atas diperoleh informasi bahwa telah terjadi peningkatan rata-rata skor tes hasil belajar sebesar 3,78 poin, persentase ketuntasan sebesar $61,50 \%$ dan peningkatan nilai tes hasil belajar dengan nilai Gain ternormalisasi sebesar 0,31 berkategori sedang. Hal ini menunjukkan bahwa proses kinerja guru dan siswa pada siklus II tercapai secara optimal.

\section{Refleksi II (Reflecting)}

Berdasarkan hasil yang diperoleh pada siklus kedua ini yaitu:

1. Aktivitas siswa dalam proses belajar mengajar sudah mengalami peningkatan yang signifikan. Hal ini dapat dilihat dari data hasil observasi terhadap indikator Aktifitas belajar siswa meningkat sebesar $32.81 \%$, yaitu dari $46,14 \%$ pada siklus pertama menjadi $78,96 \%$ pada siklus kedua. Hal ini berarti Aktifitas belajar tergolong pada kategori aktif. Kategori ini disebabkan oleh beberapa aspek Aktivitas belajar siswa pada siklus I masih bertaraf lemah. Aspekaspek tersebut antara lain aspek Oral, Motor, Emotional, Writing dan Drawing. Pada sikluk kedua peneliti menggunakan multimedia interaktif dan pembelajaran kelompok sehingga kelemahan-kelemahan pada siklus pertama dapat diperbaiki. (1)
Aspek Oral, siswa sudah aktif bertanya dan menjawab pertanyaan yang berlangsung selama pembelajaran, siswa dengan semangat bertanya akan hal-hal yang kurang ia pahami. Diskusi dalam kelompok berlangsung sesuai dengan yang diharapkan, terjadi pertukanan informasi antara seorang siswa dengan siswa lainnya. (2) Aspek Motor, siswa sudah aktif melakukan pengukuran dalam kelompoknya, keterbatasan jumlah alat yang tersedia dapat diminimalkan dengan pembelajaran kelompok ini, siswa melakukan proses pengukuran dengan benar karena mendapat simulasi pengukuran dari multimedia yang digunakan. (3) Aspek Emotional, siswa lebih teratur dan ikut melibatkan diri dalam pembelajaran. (4) Aspek Writing dan (5) Drawing, siswa dengan mudah menulis dan menggambarkan materi dan alat ukur karena multimedia sudah memvisualisasikan alat ukur dengan baik, siswa lebih mudah melihat dan kualitas gambar yang tersedia juga sudah memadai. Namun walaupun demikian pada siklus kedua ini indikator aktifitas belajar siswa telah mengalami peningkatan sesuai dengan hasil penelitian Susannto (2002) melakukan 
penelitian dengan judul Pengaruh Penggunaan Media Gambar OHP terhadap Prestasi Belajar Keterampilan Servis Tangan Bawah Bola Voli di SMUK BPK Penabur Jakarta, berdasarkan tes yang dilakukan dihasilkan bahwa terdapat peningkatan keterampilan servis tangan bawah permainan bola voli dengan penggunaan media gambar OHP dalam pelatihan servis tangan bawah permainan bola voli.

2. Dengan menggunakan multimedia interaktif dikelas dalam pembelajaran dapat meningkatkan hasil belajar fisika siswa yang ditandai dengan peningkatan rata-rata skor tes hasil belajar sebesar 3,78 poin, persentase ketuntasan sebesar $61,50 \%$ dan peningkatan nilai tes hasil belajar dengan nilai Gain ternormalisasi sebesar 0,31 berkategori sedang. Hal ini menunjukkan bahwa proses kinerja guru dan siswa pada siklus II tercapai secara optimal. Sesuai dengan hasil penelitian Selamet (2008) menjelaskan bahwa penggunaan media pembelajaran power point dalam pelajaran sejarah di SMA Al-Azhar 3 Bandar Lampung dapat meningkatkan prestasi belajar sejarah siswa di sekolah tersebut.

3. Gain ternormalisasi tes hasil belajar sebagai indikator peningkatan hasil belajar siklus II terhadap siklus I bernilai 0,31. Nilai ini menjelaskan bahwa gain ternormalisasi untuk penguatan struktur kognitif berkategori sedang.

\section{PENUTUP}

Penggunaan multimedia interaktif macromedia flash dapat meningkatkan aktivitas dengan hasil observasi terhadap aktivitas pembelajaran guru dikelas, aktifitas belajar siswa meningkat sebesar $32.81 \%$, yaitu dari $46,14 \%$ pada siklus pertama menjadi $78,96 \%$ pada siklus kedua. Hal ini menunjukan aktifitas belajar tergolong pada kategori aktif.

Rata-rata peningkatan hasil belajar siswa diperoleh hasil penguasaan siswa terhadap materi belajar tergolong baik yaitu dengan skor rata-rata 16,03 dari skor ideal 20 skor atau perolehan nilai rata-rata 80,16 dan siswa yang mencapai ketuntasan belajar 26 orang dari 32 orang siswa atau sebesar $81,25 \%$. Peningkatan rata-rata skor tes hasil belajar sebesar 3,78 poin, persentase ketuntasan sebesar $61,50 \%$ dan peningkatan nilai tes hasil belajar dengan nilai Gain ternormalisasi sebesar 0,31 berkategori sedang.

\section{DAFTAR PUSTAKA}

Abdurrahman, Mulyono. 2003. Pendidikan Bagi Anak Yang Berkesulitan Belajar. Jakarta: Rineka Cipta.

Arikunto, dkk. 2008. Penelitian Tindakan Kelas. Jakarta: Bumi Aksara.

Arsyad, Azhar. 2007. Media Pembelajaran. Jakarta: Raja Grafindo

Darnati, T.. 2001. Upaya Peningkatan Aktivitas Belajar Melalui Pendekatan Problem Posing Pada Pelajaran Matematika. Buletin Pelangi Pendidikan.

Diedrich, Paul, B.. Sardiman. 2000. Interaksi dan Motivasi Belajar Mengajar. Jakarta: Raja Grafindo Persada.

Dimyati dan Mujiono. 2006. 2009. Belajar dan Pembelajaran. Jakarta : Rineka Cipta

Djamarah, Syaiful, Bahri. 2008. Psikologi Belajar. Jakarta: Rineka Cipta.

dan Zain, Aswan. 2002. Strategi Belajar Mengajar. Jakarta: Rineka Cipta.

Djuharie dan Suherli. 2005. Panduan Membuat Karya Tulis. Bandung: Yrama Widya.

Jafrizal.

2002.

Http://infodiknas.com/?load=newsdetail $\& N e w s I D=4256$. Diakses April 2009.

Kunandar. 2008. Langkah Mudah Penelitian Tindakan Kelas Sebagai Pengembangan Profesi Guru. Jakarta: Rajawali Pers.

Sardiman. 2000. Interaksi dan Motivasi Belajar Mengajar. Jakarta: Raja Grafindo Persada.

Selamet.

2008.

http://one.indoskripsi.com/click/2827/0.

Diakses: 22 Mei 2008

Slameto. 2003. Belajar dan Faktor - Faktor Yang Mempengaruhinya. Jakarta: Rineka Cipta.

Sudjana dan Suwariyah. 1991. Model-Model Mengajar CBSA. Bandung: Sinar Baru.

Sudjana, D.. 2001. Metode dan Teknik Pembelajaran Partisipasif. Bandung: Falah Production.

Sudjana, Nana. 2009. Penilaian Hasil Belajar Mengajar. Bandung: Remaja Rosdakarya.

Susanto. 2002. http://www.pdf-searchengine.com/penelitian-efektifitas-mediapembelajaran-pdf.html. Diakses: Maret 2008.

Thamrin, dkk. 2007. Peningkatan Kemampuan Menyelesaikan Siklus Akuntansi Siswa Kelas XI IPS 1 SMA Negeri 5 Binjai Melalui Teknik Permainan Akun. Laporan Pengembangan Inovasi Pembelajaran Di Sekolah (PIPS). FE Unimed. 